\title{
Study of impact of increased number of devotees on indoor environmental quality of heritage temples of goddess Mahalaxmi at Kolhapur, Maharashtra, India.
}

\author{
Anjali Jadhav ${ }^{l, *}$, Sushma Kulkarni ${ }^{1}$, and AshishRege ${ }^{2}$ \\ ${ }^{1}$ SHIVAJI UNIVERSITY, Kolhâpur, 416004-Maharashtra (India) \\ ${ }^{2}$ GOA COLLEGE OF ARCHITECTURE, Panaji, 4030001-Goa, India.
}

\begin{abstract}
India has a great cultural heritage of temples across the country. There is a wide variety of temples of variety of deities constructed from East to West and North to South of India. Most of the temples are built centuries ago and still are in good condition and the centre of cultural activities. Mahalaxmi temple precinct is a very old precinct in Kolhapur, built in $8^{\text {th }}$ century by Chalukyan rulers. Every year lacs of devotees are visiting this temple of goddess Mahalaxmi from most of the part of India. The temple is constructed of basalt stone with beautiful intricate carving on it. This paper focus on indoor environmental quality of the temple which is deteriorated due to the impact of increased number of devotees. Some of the devotees face the problem of suffocation, fatigue, fainting, irritation, nasal congestion; as provision of vents are absent and natural ventilation is not available inside the shrine of goddess Mahalaxmi. Due to lack of air exchange and natural ventilation the indoor environmental quality is deteriorated. It is observed that the $\mathrm{CO}_{2}$ level is increased, decreased in $\mathrm{O}_{2}$ level, rise in temperature and humidity above the standard level causing discomfort.
\end{abstract}

Keywords. Heritage temple, Indoor environmental quality, comfort, devotees, natural ventilation, temperature, humidity, $\mathrm{O}_{2}, \mathrm{CO}_{2}$.

\section{Introduction}

Mahalaxmi temple is a very old temple .It is in Kolhapur near the river Panchaganga. It is situated to the north east side of the old palace in Bhavani Mandap. It is the good example of Chalukyan style of Hindu Architecture. The temple is at the centre of the temple complex and the shrines are grouped around the main temple. The plan of the temple is star shaped resembles Vesara type of Hindu Architecture. [1]

\subsection{History}

Mahalaxmi temple is in the heart of Kolhapur City. It is constructed in $8^{\text {th }}$ century. The oldest part of the present shrine is the work of early Chalukyan style. (550 A.D. to 660 A.D.) Shilahara rules of Kolhapur (990 A.D. onwards) added beauty to the temple. The old structure is constructed from close fitting mortar less stones which are brought from the quarries nearby. The stones are black basalt stones which can take high polish and intricate carvings. [2]

\subsection{Heritage listing}

As per ASI it is a grade I heritage structure and have prime importance. The city is a popular pilgrimage city and Mahalaxmi temple is the centre of the city. The old Kolhapur city is situated around this temple.

\section{Indoor Environmental Quality (IEQ)}

IEQ has major impact on the health of the building occupants. All the human beings spend maximum time of the day i.e. $80 \%$ to $85 \%$ indoors. If the IEQ is good it gives very good result on the productivity and health condition of the occupants. The efficiency, freshness, mind alertness, attentiveness increases in good IEQ. [3]

\subsection{Indoor Environmental Quality (IEQ) in Mahalaxmi Temple}

Mahalaxmi Temple is constructed in $8^{\text {th }}$ century. It is not designed for the heavy flow of devotees which is in lacs. Table no. 1 showing the number of visitors every year. Building envelope of the temple is inadequate to house such large number of devotees. Due to that the IEQ is not at comfort.

\section{Parameters of IEQ}

\footnotetext{
*Corresponding author: 02anjalijadhav@gmail.com
} 
Air quality, light quality sound quality, odour quality visual quality are the parameters of IEQ.

\subsection{Air Quality}

The parameters of air quality are a) Temperature b) Humidity c) $\mathrm{O}_{2}$ d) $\mathrm{CO}_{2}$ e) Air exchange f) Particulate matter. For comfort the temperature should be $23^{\circ} \mathrm{C}$, and $1^{\circ} \mathrm{C}$ plus and minus is advisable. The range of humidity should be $30 \%$ to $50 \%$ and the ideal level should be $45 \%$.Minimum $19.5 \%$ Oxygen is required for the good health of human being, $20.9 \%$ of Oxygen is needed for the better cognitive ability, balance and overall good health. $0.03 \%$ is the ideal percentage of $\mathrm{CO}_{2}$. High percentage of $\mathrm{CO}_{2}$ cause rapid breathing and confusion. An air exchange is how many times the air enters and exits the room in an hour. Air exchange are calculated on the base of area and number of occupants. The source of particulate matter are pollen, smoke, toxic mould and spores, bacteria, pet dander, construction dust. Corse particles are of 10 to 2.5 micrometres. [4, 5, 6, 7]

\subsection{Light Quality}

Light is the major parameter of livelihood. It is measure in terms of lux. The light should be available in appropriate level for specific task. Daylighting has adequate visibility without causing discomfort, impact on health and productivity and it is very much related to psychology of human being. Improper lighting cause eyestrain, eye irritation, fatigue and headache. $[3,8,9]$

\subsection{Sound Quality}

An unwanted sound is noise and it affects the health, wellbeing of occupants. Loud noise can cause hearing loss, stress and impact on heart. Annoyance can be disturbing among individuals due to increased noise. As per research, $40 \mathrm{db}$ is low sound and above $55 \mathrm{db}$ it is matter of concern. Meaning of acoustic comfort is having the correct level and quality of sound to use the space as planned. $[3,10]$

\subsection{Odour Quality}

Odour plays a great role in the indoor environments. They are quite significant for the IEQ. Odour is distinctive smell especially an unpleasant one. Bad odour cause headache, nausea and temporary symptoms which bother people.

\subsection{Visual comfort}

The space should be clutter free, with good circulation and good visual, aesthetical quality.

\section{Problem Identification}

Every year in the festival season of Navratri two medical camps are arranged for the devotees to take care of the medical emergency. Most of them report shortness of breath, fainting, giddiness, irritation, nasal conjunction. Most of the children cry as they enter the shrine which is full of devotees and very crowdie.

Table 1. Visitor's data 2018-2019

\begin{tabular}{|c|c|}
\hline Month & $\begin{array}{c}\text { No. of } \\
\text { visitors }\end{array}$ \\
\hline Nov-18 & 713583 \\
\hline Dec-18 & 577617 \\
\hline Jan-20 & 776190 \\
\hline Feb-20 & 452059 \\
\hline March-20 & 733580 \\
\hline April-20 & 905725 \\
\hline May-20 & 584848 \\
\hline June-20 & 489003 \\
\hline July-20 & 316503 \\
\hline August-20 & 451930 \\
\hline Sep-20 & 611353 \\
\hline Oct-20 & 3175745 \\
\hline
\end{tabular}

\section{Objective}

The objective of the paper is to study and analyse the impact of increased number of devotees on the indoor environmental quality of the heritage temple of goddess Mahalaxmi at Kolhapur.

1. To study and understand the heritage value of the temple and the indoor environmental quality of the temple.

2. To study and understand the number of devotees visiting the temple through the year and on the festival seasons.

3. To measure all the parameters of indoor environmental quality with the help of various instruments and analysis of the data.

4. To derive a broad conclusion on the basis of the data collected and the analysis.

\section{Methodology}

The work is carried out in Mahalaxmi Temple, in the month of September 2019 and October 2019. These months are very important as the main festival of Navratri is in these month and lacs of devotees visit temple during 
this period. To study the IEQ of the temple the instrumentation is carried out at 5 locations of the temple. Figure 1 shows the location of the instrumentation. The temperature and humidity is measured by Kestrel-4000 pocket weather tracker. $\mathrm{CO}_{2}, \mathrm{O}_{2}, \mathrm{Ch} 4$, are measured by air sensor Drager-X-am 5600. Light is measured by light meter LX-101.

\section{R1-Garbhagruha}

R2-darshan Mandapa

R3-Kasav Mandapa

R4-Ganapati Chowk

R5-Outside the temple

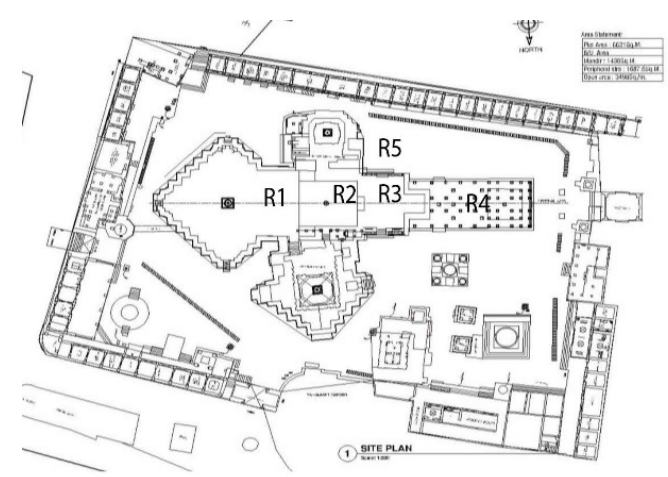

Fig. 1Instrumentation in the temple.

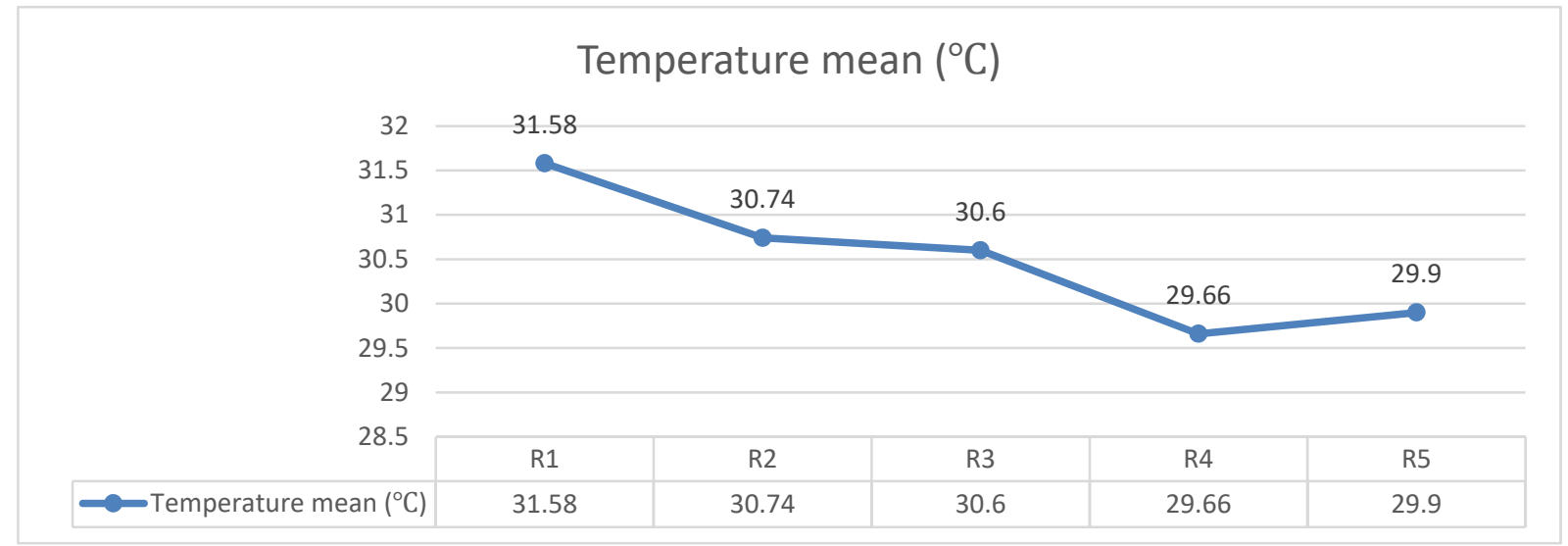

Fig. 2 Graph showing temperature at 5 locations of the temple

\section{Humidity (\%)}

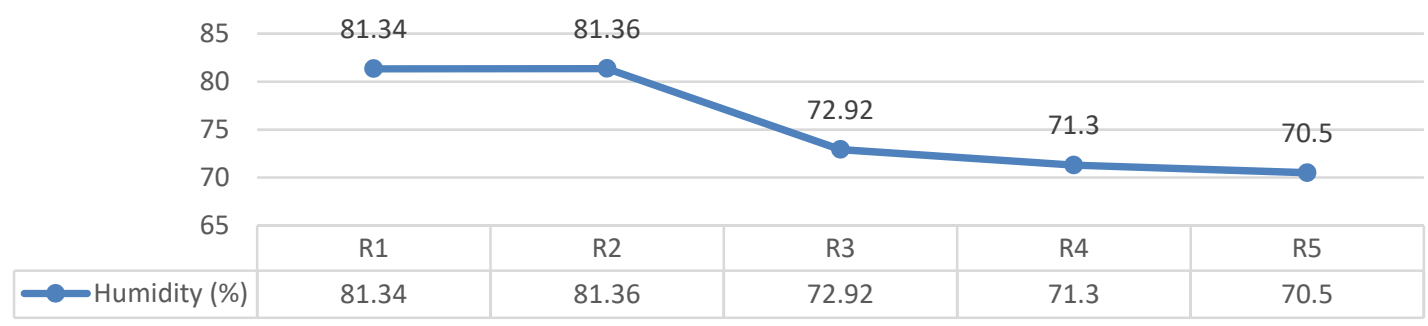

Fig. 3 Graph showing Humidity in the temple at 5 locations

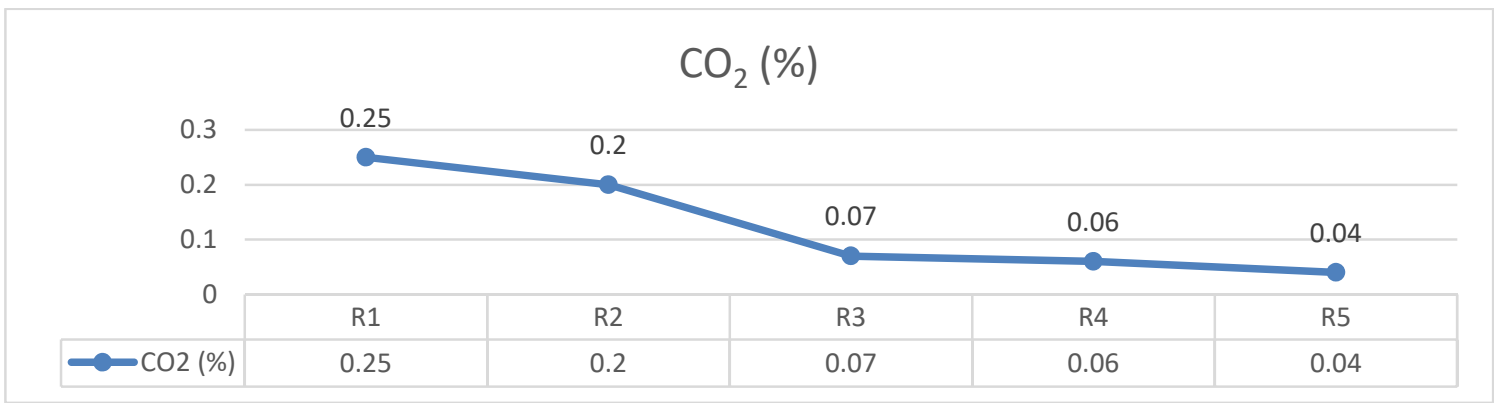

Fig. 4 Graph showing $\mathrm{CO} 2 \%$ in the air of the temple at 5 locations 


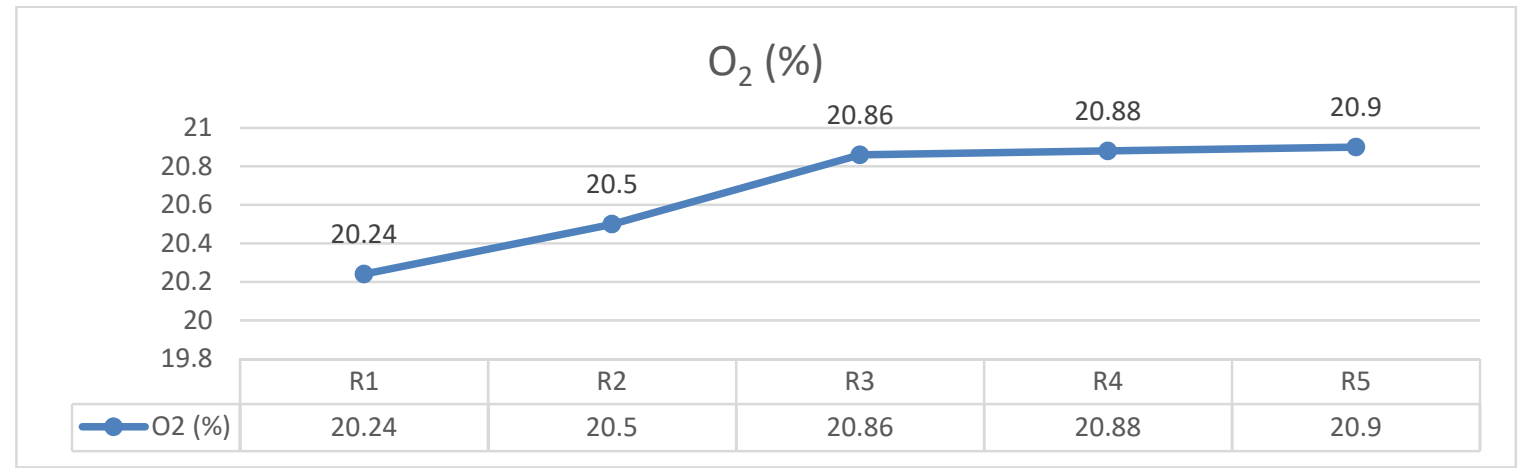

Fig. 5 Graph showing $\mathrm{O} 2 \%$ level in air of the temple at 5 locations

\section{Data Analysis and Conclusion}

From the analysis of the temperature graph (figure no. 2) it is observed that the temperature of the Garbha-gruha R1 is more than $1.7 \mathrm{OC}$ than the outside temperature R5. Devotees' density is maximum at location R2, they stay there at least 10 minutes. The area per person available is 0.35 sq. mt.; which is very suffocating. The humidity level is $81.34 \%$; which more than the comfort standard, causing discomfort. (Figure no.3). The $\mathrm{CO}_{2}$ level is $0.25 \%$ whcih is more than the standard level. (Figure no.4), $\mathrm{O}_{2}$ level is also reduced by $0.66 \%$ (Figure no.5) The wind speed is $0 \mathrm{~m} / \mathrm{s}$ as there is no cross ventilation in the Darshan mandapa, and the vents above the shrine are closed. The air exchanges are not up to standards and very less per hour. The noise level in the shrine is $82 \mathrm{db}$. which is very chaotic and no silence is observed. Inside the temple there are various smell created by fresh flowers and decaying flowers, essence sticks, burning oil lamps and most objectionable and voluminous smell is of visitors sweat. Decreased $\mathrm{O}_{2}$ level, increased $\mathrm{CO}_{2}$ level, increased humidity and temperature, increased noise level causes discomfort. From the observations it is concluded that the
IEQ in the temple is deteriorated and may cause an impact on the health of the devotees.

\section{References}

1) P. Brown, B. Indian Architecture (Buddhist and Hindu Periods), 62.

2) B. Maharaj, Karveer Nivasini shree mahalaxmi -, 20.

3) ISHRAE Position Paper on Indoor Environmental Quality, August (2015).

4) ASHRAE STANDARD $\mathbf{5 5}$ (2017)

5) L. Zagreus, C Huizenga, E Arens., D Lehrer. , I.A., J. 65(2004)

6) D.Kolokotsa, A.pouliezous, G.stavrakakis, C.Lazos. B. \& E., J. 44 (2009)

7) S. Tanabe, M. Haned, N. Nishipana, Waseda Uni, Rehva J.-June (2007.)

8) B. Rechard Hugges, S. D., E.P., 105, 2865-2870. (2017)

9) K. Fabbri, L. Tronchin, S.D, E. P. 78, 2778-2783. (2015)

10) X. Leong, E. Essah, S.D., E. P., 132, 87-92. (2017)

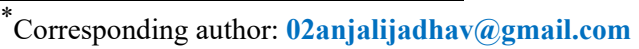

